\begin{tabular}{c} 
Volume and Issues Obtainable at Center for Sustainability Research and Consultancy \\
Journal of Accounting and Finance in Emerging Economies \\
ISSN: 2519-0318 ISSN (E) 2518-8488 \\
Volume 7: Issue 1 March 2021 \\
CSRC \\
Journal homepage: $\underline{\text { ww.publishing.globalcsrc.org/jafee }}$ \\
\hline
\end{tabular}

\title{
Access to Own Dwelling through Ijarah at Islamic Banks and State-Owned Housing Scheme in Pakistan
}

\author{
${ }^{1}$ Naseem Razi, ${ }^{2}$ Rashida Zahoor, ${ }^{3}$ Muhammad Asif Safdar, ${ }^{4}$ Jibran Jamshed \\ ${ }^{1}$ Associate Professor of Law, FSL., International Islamic University, Islamabad, Pakistan, \\ naseem.razi@iiu.edu.pk \\ ${ }^{2}$ Assistant Professor, Department of Law, University of Sahiwal, Sahiwal, Pakistan, \\ rashidazahoor@uosahiwal.edu.pk \\ ${ }^{3}$ Assistant Professor, Principal of Gillani Law College, Bahauddin Zakariya University, Multan, \\ Pakistan, principallaw@zu.edu.pk \\ ${ }^{4}$ Assistant Professor, Department of Law, Islamia University of Bahawalpur, Pakistan, \\ jibran.jamshed@iub.edu.pk
}

\begin{tabular}{l} 
ARTICLE DETAILS \\
\hline History \\
Revised format: January 2021 \\
Available Online: March \\
2021 \\
\hline Keywords \\
Housing and Development, \\
low-cost housing, \\
finance, ijarah, house \\
financing Pakistan
\end{tabular}

JEL Classification: M40, M41

\section{ABSTRACT}

Purpose: Access to a safe dwelling is one of the necessities of life and an indicator to reveal the economic development of a country. In Pakistan, however, the majority of the people do not have their dwelling rather have to spend their life in renting homes or in slums. To overcome the housing shortfall, the State Bank of Pakistan has pronounced a low-cost housing scheme for the poor and the lowincome segment of the society while the Islamic banking sector also offers ijarah facility to purchase or to construct own dwelling and claims to work in the objective of Islamic legal system. Therefore, this study aims to analyze critically, ijarah and state-owned low-cost housing schemes from the public insight. Design/Methodology/Approach: This research aims to utilize analytical, theoretical, and empirical methods of research rather than some combination thereof by utilizing experimental reasoning based on naturally occurring data, reports, and surveys. To evaluate ijarah and government housing scheme from public insight, a survey of 100 salaried persons has been conducted by way of the questionnaire at different companies in District Rawalpindi. Findings: This study found that Pakistan is suffering from the acute issue of lack of own dwelling. The result of the conducted survey reveals that the majority of the employed people showed more trust in the stateowned housing scheme than ijarah at Islamic banks. Those people showed their interest in the state-owned housing scheme than ijarah at Islamic banks. Implications/Originality/Value: The practical approach to ijarah at Islamic bank found in trust deficit concerning the public insight. That ijarah does not provide low-cost homes to the homeless people, hence not serving by Shari'ah. The current policy of the state provides an opportunity to ijarah to facilitate poor people by softening its terms and conditions and by way of qard-ehasanah. 
Corresponding author's email address: jibran.jamshed@iub.edu.pk

Recommended citation: Razi, N., Zahoor, R., Safdar, M. A. \& Jamshed, J. (2021). Access to Own Dwelling through Ijarah at Islamic Banks and State-Owned Housing Scheme in Pakistan. Journal of Accounting and Finance in Emerging Economies, 7(1), 9-22

\section{Introduction}

To examine the level of economic development of a country, the economists recommend studying the level of poverty among the people and for this purpose, adopt different measures like Foster J, (1984), Rowntree, BS (1901), Desai M. J. (1984), Chakaravarty (1983) evaluated the edifice of poverty in terms of income only, while others, such as Drez and Sen (1989), Campbell and Kracaw (1993), Kidwell and Peterson (1995) studied poverty in broader terms as a state which encompasses lack of assets, physical weakness, isolation, vulnerability, and powerlessness and viewed poverty as a sever failure of human capability. However, both theories viewed own dwelling as a necessity of life and the issue of the lack of adequate housing is the relative poverty and a state of living conditions below the average living standard of a society.

Providing affordable housing has become a challenge all over the world. It is for this reason that almost all the declarations of UNO (United Nations, Organizations, 1948) regarding human development have declared the issue of access to adequate housing as a fundamental right and as an important factor for economic development (http//www.uno.org/declarations). ${ }^{1}$

\section{Literature Review}

Haugen, (2000) discussed economic development and stability of the society concerning the gross domestic product of a country which is measured through the living standards of a nation and pointed out that access to own housing is an important component of GDP and standard of living in a society. Razali, (2002) and Annez \& Wheaten C., (1984) pointed out the issue of access to own dwelling has been considered as a part of the fundamental rights of the human being. It is a necessary component of life without which a human being remains unstable, undeveloped and poor. While a large number of poor people consume housing services below the socially desirable level. Neil, (2005) and Dingeldey \&Rothgang, (2002) pointed out that a man can neither be an intellectual nor be a successful man unless he has sufficient material to survive. That the prosperity of the citizens enables them to contribute to the development of society despite their diverse strengths, weaknesses, interests, and backgrounds. In the same manner, the Islamic economic system considers housing as a basic component of the necessities of life and one of the major objectives of Shari'ah (Nu'mani, 1990; Ashmawi,1987; alYubi, 1998; Warde, 2006).

Kidwell, D.S., Peterson, R. L., \& Blackwell, D.W (1995) pointed out that in each economy, social welfare programs permeate life in the market and determines its future course and directions. Espionage Anderson (1992) also described that "social factors are very crucial for the market economy. They are often seen either as hidden or as ideal dimensions of the market, although they exist analytically and can be reached empirically so that they can become documented as real in the public mind."

\footnotetext{
${ }^{1}$ Such as UDHR (Universal Declaration of Human Rights 1948, Article 25 (1 )), ICESCR (International Covenant on Economic, Social and Cultural Rights, Article 11(1)), UND on Social Progress (United Nations Declaration on Social Progress and Development, 1969), and UNVD on human development (The United Nations Vancouver Declaration on Human Settlements, 1976). Available at www.uno.org/declarations.Last accessed on 20-11-2020.
} 


\subsection{Analysis}

The housing sector, in the developed states, has been considered as a state-owned system while its cost is considerably influenced by the pattern of government assistance through tax relief, direct subsidies, and rebates in the light of a family budget (Commons, 1998; Bruyn, 1999; Marshall, 1997). For instance, in 1949, the government of France launched a policy for the construction of 20,000 dwellings a month for 40 years to overcome the crisis of housing shortfall and pronounced to transform it into an industry (Bullock, 2008).

Likewise, in England and Wales, until the 1930s, 90\% of housing was rented privately which was reduced up to $43 \%$ by the 1970 s through government policies. In 1977, the situation got improved and the position was that about 56\% of the dwelling was owner-occupied, $31 \%$ rented from local authorities, while the rest 13\% were rented from private landlords (Erikson, 1985; Aaron, H. J., 1999).

In the UK, under Housing Act 1980, a tenant has the right to buy a house with a discount of 33-50\% of the market value. The average house prices range across the country between $£ 129,750$ in northeast England and $£ 484,716$ in London, while average weekly earnings range from $£ 483$ in the East Midlands to $£ 671$ in London (The UK Local Authority Building Control Survey,2018).

On the other hand, in the USA, tenants have to pay only $30 \%$ of the public housing cost based on income. In the same period, in the USA, homeowners enjoy substantial concessions that allow deduction of housing cost from taxable income (USA Center on Budget and Policy Priorities Report, 2017).

As far as the issue of housing in South Asian countries, availability of housing is currently, limited to upper -income population, while the availability of housing finance to the middle and lower-income group is a big challenge (Lall, 1989; Nenova, 2008). The rapid increase in the population, land price, poor infrastructure, deficient financial system, the dearth of long term funding, limited developer finance, and informal population group have made it difficult to address the challenge of providing affordable low-cost housing for the majority of the population (Asian Development Bank, 2018 ).

A study (World Bank Report 2014) revealed that about more than one billion people of the world are homeless, 14\% of which are in South Asia. Vinay D. Lall, (1987) asserted in his studies that the biggest issue of the housing sector is the non-availability of long-term finance to individual house builders on any significant scale. And this issue is still persistent in South Asian housing plans.

\subsection{Economic Development and Housing Shortfall in Pakistan}

Pakistan is consisted of about 220,892,340 million people with a $2.4 \%$ growth rate. It is one of the youngest countries in the world whose $64 \%$ of the population is under the age of 29 yrs., while $30 \%$ are between the ages of $15-29$ (https://www.worldometers.info/world-population/pakistan).

The economy of Pakistan is considered as developing consists of a low per capita income, lower saving, and less investment. The average GDP growth rate is estimated at $4.94 \%$ during the period 1952---2018 with the highest rate of $10.22 \%$ in 1954 while the lowest was about $1.80 \%$ in 1952. In the year 2018, the GDP growth was about 5.79\% ranked Pakistan $147^{\text {th }}$ in the world (State Bank of Pakistan Report, 2018).

The following graph shows the major sectors of GDP in Pakistan. 


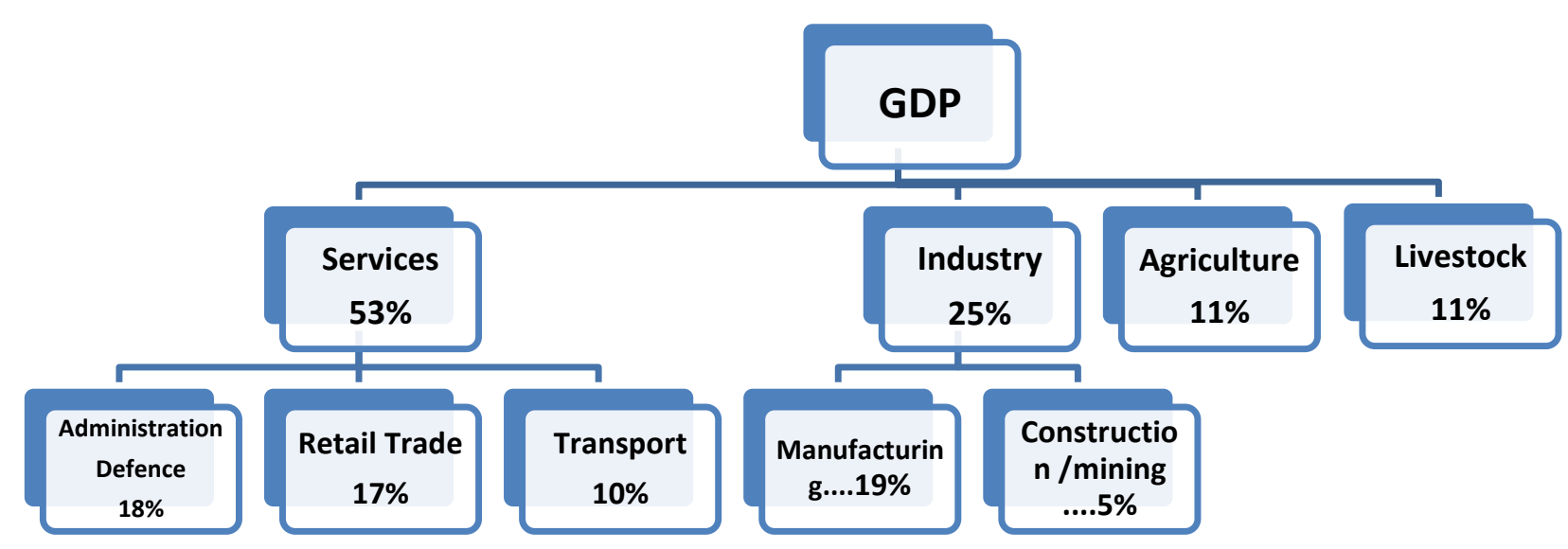

Figure No 1: Major Sectors of GDP in Pakistan

This figure shows that both the construction and mining sectors constituted only 5\% of total GDP, hence there is a widened scope for growth in the construction sector (https://tradingeconomics.com/pakistan/gdp-growth-annual).

Like other South Asian countries, Pakistan is also suffering from the issue of urbanization as living standard is better in cities than villages. A study reveals that until 2000, 33\% of the total population were living in cities while in 2017 about $39 \%$ of the population with an increase of $6 \%$. However, still, $63.6 \%$ population is living in rural areas with a decrease of $2.4 \%$, which was $65.6 \%$ in 1998 (Pakistan's 6th Population and Housing Census, 2017).

Table 1.

\begin{tabular}{|c|c|c|c|}
\hline \multicolumn{4}{|c|}{$\begin{array}{l}\text { Urbanization in Pakistan: Census- } 2017 \\
\text { (An increase of 100\% since 1998) }\end{array}$} \\
\hline & Province & Urban Population & Rural Population \\
\hline 1 & Sind & $52.02 \%$ & $47.8 \%$ \\
\hline 2 & Punjab & $36.71 \%$ & $64.29 \%$ \\
\hline 3 & Khayber Pakhtoon Khawah & $37.37 \%$ & 62.63 \\
\hline 4 & Baluchistan & $20 \%$ & $80 \%$ \\
\hline 5 & Islamabad Capital Territory & $50 \%$ & $50 \%$ \\
\hline
\end{tabular}

(The Pakistan Bureau of Statistics (PBS) Census 2017).

According to the census 1998, the share of urban households was 37.5\%, while in 2018 it increased up to $67.6 \%$. The living standard, however, is miserable in Pakistan as only $0.1 \%$ of GDP is spent on water supply and sanitation. Further, an increase in the share of the urban population also led to an increase in the slums with a miserable living condition (THE PAKISTAN INFRASTRUCTURE REPORT, 2018).

\subsection{Housing Shortfall in Pakistan}

So far as concerned the issue of the housing sector in Pakistan, for many decades, Pakistan has been suffering from the issue of the acute housing shortfall, which is increasing with the increase in population and the situation is going on worse to worst. Among 220,892,340 million people, only 32 million are households with 6.45 persons which count for only $15.38 \%$ of the population (Pakistan Bureau of Statics Report, 2018). A study reveals that Pakistan ranks $8^{\text {th }}$ among those 10 countries which hold $60 \%$ of substandard housing around the world (http//devpakistan.com/2017-18).

Pakistan Bureau of Statics Report (2018) pointed out that among homeless people 80\% are from a low- 
income group and poor class of the society. State Bank of Pakistan Report (2019), reveals that in 2009, the housing shortfall was about 7.57 million units, while in 2019, the issue has increased and the housing shortfall reached more than 10 million units.

As housing construction is dependent upon the national gross saving rate so, sufficient saving is needed for this purpose. Looking into the situation of gross saving rate in Pakistan, the Economic Survey (2018) reveals that the average gross rate is $10.0 \%$ with the highest GSR about $17.4 \%$ in 2004 and the lowest $5.5 \%$ in June 2018.

And all this has made the government handicap to improve the level of infrastructure and social services which made the situation pitiable by international standards while the development of infrastructure is a prerequisite for sustainable economic growth and human development.

\subsection{State-Owned Low-Cost Housing Finance 2019-2021}

To overcome the issue of housing shortfall, the government of Pakistan has launched a Policy for Promotion of Low-Cost Housing Finance 2019-2021. The State Banks' pronounced policy for low-cost housing plan 2019-2021 has estimated that the annual demand for new homes is approximately 700,000 a year.

The policy has been designed in light of both local and international market conditions. Among the objectives of this scheme are "increasing housing finance portfolio of banks/DFIs from current, Rs. 83 billion to Rs. 250 billion by June 2021, along with increasing the number of borrowers to 200,000 from the current 68,000".SBP to facilitate provincial governments and state-owned enterprises to avail housing finance from banks.

The eligibility criteria and necessary conditions to avail low-cost home financing areas:

Home ownership= the First time

Maximum monthly income of a borrower= Rs. $60,000 \mathrm{p} / \mathrm{m}$

Low-cost House financing= Loan up to Rs. 2 million

Property value $=$ up to Rs. 2.5 million

SBP loan to the borrower====up to Rs. 1 million(50\% of loan)

Rate of return=========== $1 \%$

Loan Tenor $=$ Up to $12 \frac{1}{2}$ years

The Remaining $50 \%$ of the loan amount shall be provided by the banks/DFIs from their sources at a fixed rate of up to $12 \%$ or a variable rate of 1 -year KIBOR plus a risk premium up to $4 \%$.

To motivate banks to contribute to achieving low-cost housing targets, certain relaxations have provided for the banks such as the general reserve requirements, portfolio of banks/DFIs to be waived off; Bank/DFI's exposure to be exempted from the exposure limit of $10 \%$ for real estate sector; the Microfinance banks will be allowed to increase housing finance up to Rs. 1 million from Rs.500, 000. For stability, a standardized loan application form has been issued from the PBA to streamline loan processing by banks/DFIs. Further, a tax incentive to builders and financial institutions has offered upon income derived from low-cost housing. Certain steps have been taken for capacity building and awareness creation in public.

However, the success of the newly launched program is dependent on the government's persistent concern to achieve the set target. Mohd Razali (2002) has described that the most common complaint about the public housing sector is unnecessary delay in the process of approval of an application submitted for land development, conversion subdivision and completion of construction.

\subsection{Access to Own Dwelling through Ijarah: Pakistan Perspective}


Islamic banking and financial sector is an emerging industry and is a competitor to the conventional banking system and financing (Chhapra, Ahmed \& Others, 2018).

It is a widespread belief among the Muslims that the Islamic banking and financing system must operate in the light of the objectives of Shari'ah to eliminate capitalist banking interest, to eradicate the exploitation of the poor segment of society, and to maintain a balance economic order and social justice in the society(Razi, 2014).

Islamic Banking Bulletin, (September 2018), explored that the share of Islamic banking and finance in the market is about $13.6 \%$, which is growing at the rate of $3.2 \%$ annually. By substituting lease at conventional banks, the Islamic banking system introduced ijarah ( اج ) by way of diminishing musharkah. It is a contract based on profit, sharing between the bank and the client. The corpus of the leasing object, such as a car, a house, or machinery remains in the ownership of the bank, concerning its share and only its usufruct is transferred to the client for an agreed period, at an agreed consideration(Warde, 2006; Yusuf, 1994).

\subsection{Affordability of Ijarah in Pakistan: A Case Study, I-10 Sector Islamabad}

In Pakistan, both conventional and Islamic banks offer home financing and claim to be accommodated by way of mutual agreement. It is considered a bilateral agreement where the bank buys a commodity, e.g., the house from a selected dealer and leases it to the client at an agreed (on the terms and conditions of the bank) monthly rent and period. Keeping aside the poor segment of the society (more than 50\%), the middle-class community and salaried persons mostly seek car leasing or house financing.

For an effective result, a case study of Home Financing is being presented. ${ }^{\mathrm{i}}$ For instance, a civil servant/government officer of 19 scale's, residing in the middle-class sector 1-10, Islamabad (where $70 \%$ people are salaried and living on hiring) with five households, wants to purchase a home of 1000 sq feet in 1-10 sector (worth Rs.10 million) through ijarah an Islamic bank.

The particulars of the client, Mr. X are as under:

The job of Mr. X: Government Employee (19 scales)

Age: 45 years old

Disposable Income: Rs 100,000 p/m (the highest salary package)

Minimum utility expenditure: Rs 80,000 p/m (wife and three children)

Others: Rs. 10,000

Savings: Rs. $10,000 \mathrm{p} / \mathrm{m}$

Mr. X provides an amount of Rs. Six million or $60 \%$ of the said house. The particulars of the contract will be as given in the table below

\section{Table 3.}

\begin{tabular}{|l|l|l|l|}
\hline \multicolumn{2}{|l|}{ PROPORTIONATE RENT ANALYSES } & Client Share & Total Shares \\
\hline ===== & Bank Share & 6 Million & 10, Million \\
\hline Investment share & Rs. 4 Million & 3 & 5 \\
\hline Proportionate share & 2 & 270 & 450 \\
\hline House in Units & 180 & 67100 & $1,11,833$ \\
\hline $\begin{array}{l}\text { Rent of the house for } \\
\text { Ist month }\end{array}$ & Rs.44733 & & \\
\hline
\end{tabular}

This table shows that house when is divided into units in light of the proportion of investment by both parties.

The share of the bank is 180 Units while the client has 270 Units and the total units of the house will be 450 .

In the light of the above-mentioned formula, the bank charges Rs. 44733/180 U while the client may 
charge Rs.67100/270 U. Thus, the rent for the first month of the whole house/450 units will be Rs.1, 11,833 while in 2014 , the said house was available at the rent of Rs.30000 per month. According to the prevailing market trend and rent practice, the rent which might be charged by the bank/180 units should be Rs. 12000 and if we add an annual increase of $10 \%$ in the rent of the said house w. r., to bank share, it would be Rs.13200 next year. Thus, the middle class cannot avail of home financing by way of ijarah (Razi, 2014).

\subsection{Ijarah as a Reliable Tool of Home Financing: Public Insight}

To inquire into the question of whether Pakistani people have an awareness about injure as a reliable and affordable instrument of home financing or not, a survey of 100 employed persons was conducted at different Organizations of Rawalpindi in June-July 2020. The target was the salaried segment of the society between 25 to 60 years of age. The objective was to collect data on the awareness, effectiveness, and reliability of ijarah in Pakistan.

To collect first-hand information through a questionnaire about four volunteer students were engaged. The questionnaire consisted of 9 questions. The result of the survey against each question has given below:

\section{Question no 01. Do you reside in your house or on rent?}
a. Own,
b. Rented

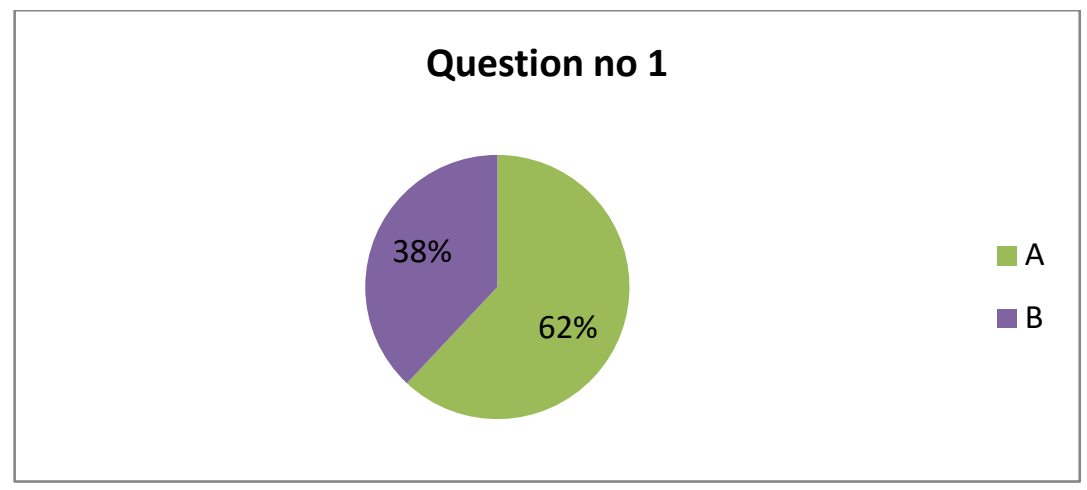

Among 100 employees about $62 \%$ opted for option A while $38 \%$ selected option B.

\section{Question no 02. Is your housing by way of inheritance or by your own means?}
a. By way of inheritance,
b. By own means

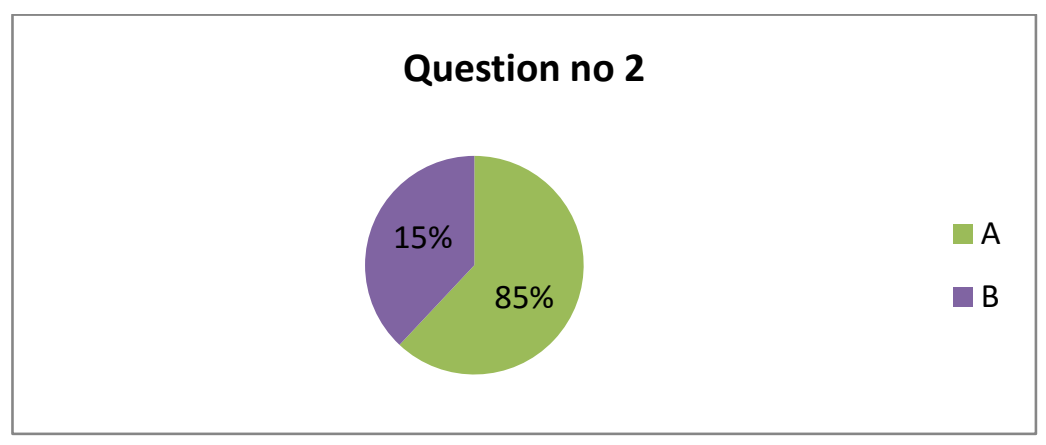

Among 100 employees about $85 \%$ opted for option A while $15 \%$ selected option B.

Question no 3. Do you know that Islamic banks offer home financing by way of ijarah?
a. Yes,
b. No 


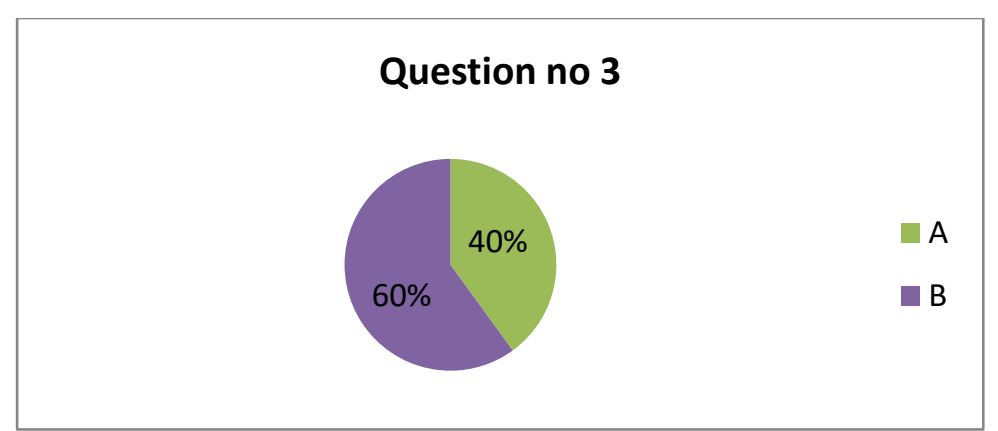

Among 100 employees about $40 \%$ opted option A while $60 \%$ selected option B.

Question no 04. Are you aware of the terms and conditions of ijarah, at Islamic banks? a. Yes, b. No

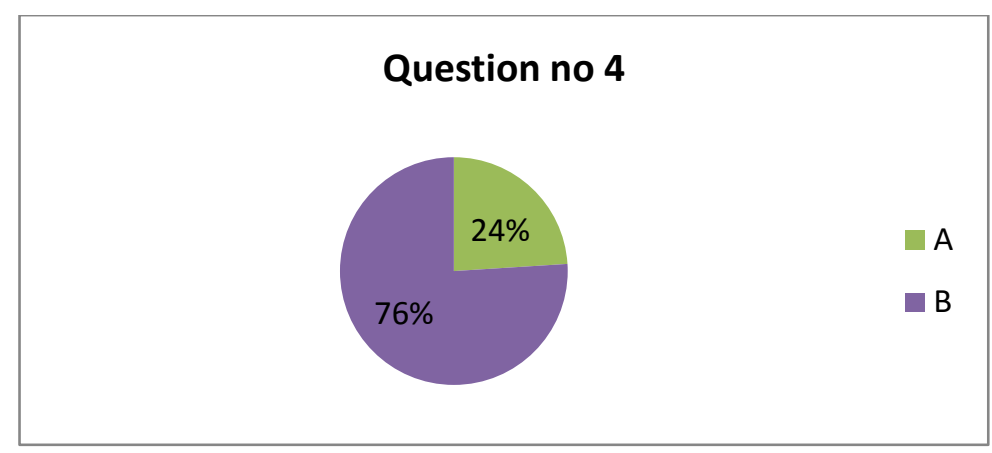

Among 100 employees about $24 \%$ opted for option A while $76 \%$ selected option B.

Question no 05. Did you ever try to avail ijarah mode of home financing at Islamic banks? a. Yes, b. No

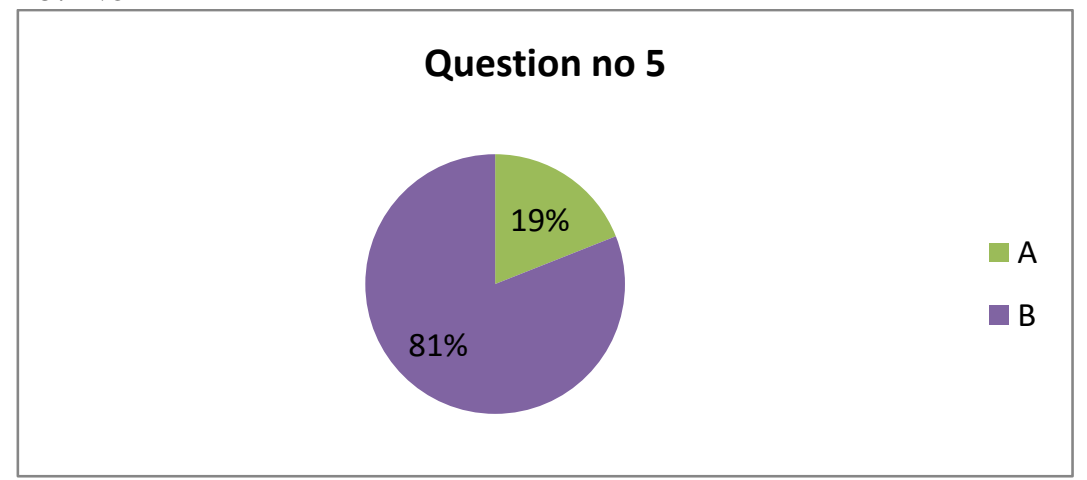

Among 100 employees about 19\% opted option A while $81 \%$ selected option B.

\section{Question no 06.}

If not, why?

a. Have no savings,

b. Felt no difference between Islamic and conventional modes of home financing

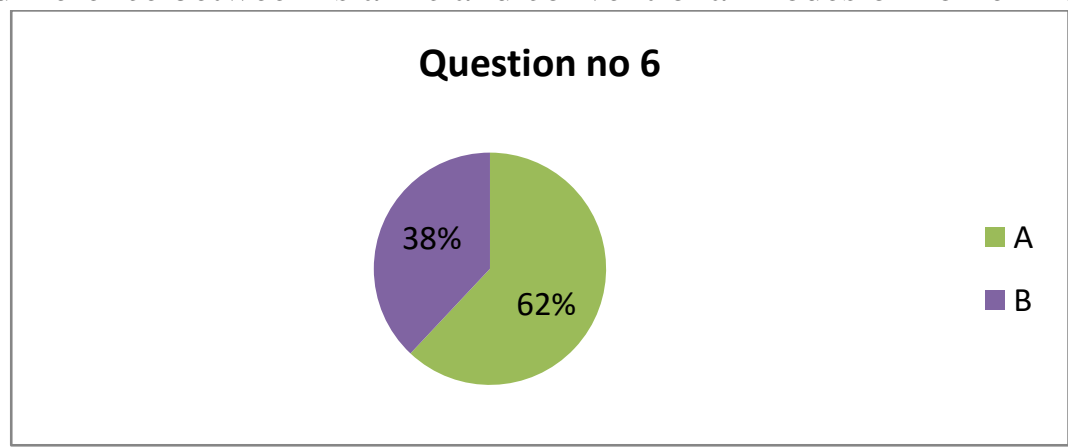


Among 100 employees about $62 \%$ opted option A while $38 \%$ selected option B.

Question no 07. Does home financing at Islamic banks support the poor segment of society? a. Yes, b. No

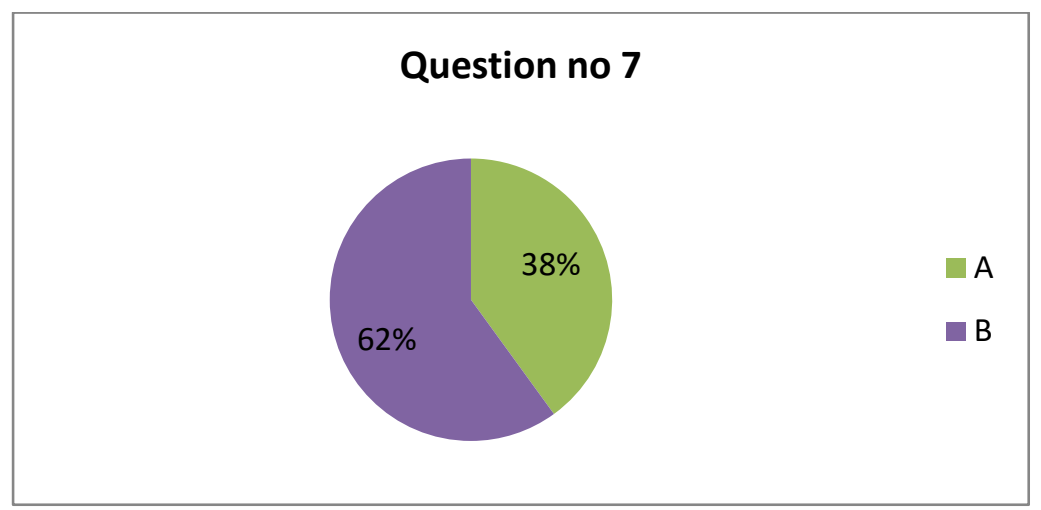

Among 100 employees about $62 \%$ opted option A while $38 \%$ selected option B.

Question no 08. What is your opinion about the low-cost housing scheme recently launched by the current government?

a. Affordable, b. Not affordable

Question no 8

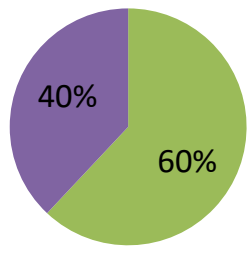

A

B

Among 100 employees about $60 \%$ opted option A while $40 \%$ selected option B.

Question no 09. If you want your housing, which of the following offers would you adopt?

a. The government scheme, $\quad$ b. ijarah at an Islamic bank

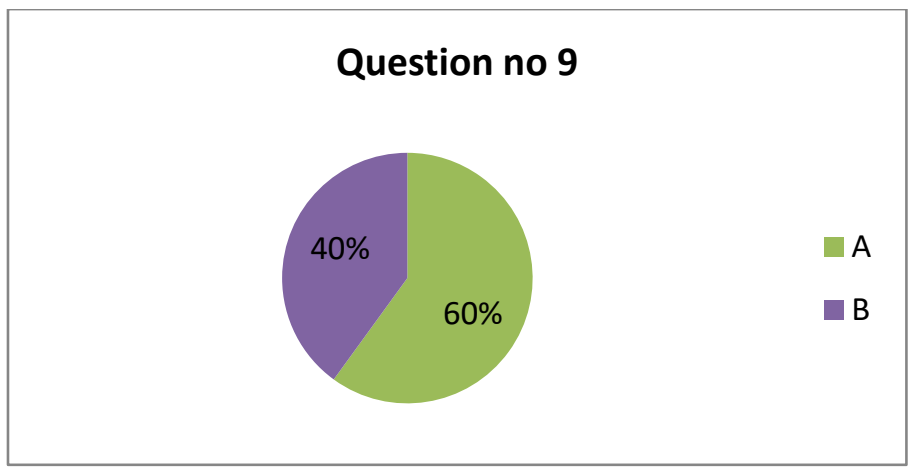

Among 100 employees about $60 \%$ opted option A while $40 \%$ selected option B.

The result of the above-mentioned survey thus, reveals that among 100 respondents, only $24 \%$ have awareness about ijarah while $19 \%$ of respondents tried to avail ijarah financing, but could not avail it due to hard conditions imposed by Islamic banks and huge amount as saving. The majority of the respondents, $62 \%$ regretted having such a huge amount as savings as required by Islamic banks to avail ijarah facility. 
Contrary to it, $60 \%$ of the respondents acknowledged the affordability of low-cost housing schemes launched by the current government. In the same manner, $60 \%$ of respondents expressed their trust in adopting the government policy of low-cost housing in comparison to ijarah at Islamic banks. This survey thus shows that Islamic financing in Pakistan lacks public trust, reliability, capacity building, and awareness creation among the public while these are core principles of business and finance.

Now, the issue of public perception and affordability of ijarah facility for low income and salaried segment in Pakistan is explored from a different angle by way of the case study.

Although the Islamic banking and finance sector grew noticeably in Pakistan by about $30 \%$ during the last few years, yet net financing in ijarah has been decreasing dramatically (Noshin \& Perveen,2014) Likewise, the issue of non-compliance of the principles of Islamic finance is a hot issue to debate. A study found that Islamic automobile ijarah financing offered by Islamic banks is not following Islamic Shari'ah guidelines and principles completely (Chappra nd Others, 2018).

\section{Findings and Recommendations}

Considering the current socio-economic conditions of Pakistani society, it is concluded that home financing by way of ijarah is not affordable for the majority of the people.

There are very hard conditions such as the client is required to provide at least $60 \%$ of the leased home along with a sufficient amount of his bank account before disbursement of ijarah that must be equal to the first three installments as the lien. The rent charged by the bank of its units is very high almost double of the market trend.

Moreover, the prescribed rent (Rs. 44733/180 units) decreases very slowly like after three months payment of Rs. 134199 and after the purchase of three units of the house from the bank, only a few hundreds (Rs.745) will decrease and the rent will be Rs.43988 against 176 units.

It seems that the current system of ijarah is based on the notion of high profit earning rather than in the light of the objectives of Shari'ah. In a state like Pakistan, where almost $50 \%$ of the population are living below the poverty line with the worst living conditions, seeking higher profit or rent leads to the exploitation of the poor lessee which is against the objectives of Islamic financing and is prohibited by Islam.

The results of the survey also lead that Islamic financing lacks reliability, capacity building and awareness among the public while these are the core principle of business and finance.

The study also concludes that the people have a trust deficit upon Islamic financing and have more trust in the current policy of the low-cost housing policy of the government than on ijarah.

It is also concluded that collecting firsthand information through a questionnaire and survey is an effective practice for the creation of awareness among the public and to motivate people to avail home financing by way of ijarah.

This study thus, recommends softening the terms and conditions of home financing through Islamic financing. It recommends revising the policy of ijarah in the light of maqasid al-Shari'ah as access to reasonable housing is one of the necessities of life without which life cannot be sustained.

In Pakistan, the policy of ijarah should be redesigned in the light of the social welfare policies as Islamic financing can contribute as a vibrant tool for low-cost home financing by adopting a flexible 
policy of ijarah. For the employed and middle-class segment, it should provide home financing in the light of the monthly income and expenditures of the applicant at minimum profit/rent at the time when the agreement is made and sale is done not with so-called rent or profit determined in the light of the duration of the contract, which is, in fact, the conventional mode of markup/interest.

For the poor class, Islamic banks should offer home financing by way of qard-e-hasanah to ensure social welfare on behalf of Islamic financing. With a reformed structure of ijarah, an effective campaign should be launched by way of seminars, surveys, interviews of homeless people to create awareness and trust in the public. It will result in highlighting the injure as a vibration mode of home financing, which would work under maqasid al-Shari'ah.

\section{References}

Aaron, H. J. 1999. Shelter and Subsidies. Washington: The Brooking Institutions.

Ahmad, Yusuf. 1994. Contemporary Experience of Islamic Banks: A Survey, in Elimination of Riba from the Economy. Islamabad: Institute of Policy Studies.

Al- Yubi, Muhammad Sa d bin Ahmad.1998. Maqasid al-Shariah al-Islamiyyah 'Ila qati 'uha bil 'Adillah.

Alfred Marshall. 1980. Principles of Economics. Cambridge: Cambridge University Press. Allama, Shibli Nu'mani. 1989. Al-Farooq: Biography of Umar. Lahore: Mansoor Publications.

Aristotle. 1956.The Nicomachean Ethics. trans., H. Rackham M. A. London: William Heinemann Ltd. Asian Development Bank. Key Indicators for Asia and the Pacific.( 2018). Country Tables @ https://data.adb.org/sites/default/files/pakistan-key-indicators-2018.

Ashmawi, Muhammad Sa id. 1987. Usul al-Shari'a. Beirut: Dar Iqra'.

Barker, R. G. 1946. The Politics. trans. Oxford: Oxford Press.

Ben B. Seligman. 1962. Main Currents in Modern Economics. New York: Free Press.

Brown \& Egon. 1994.The Traditional Centrally Planned Economy and its Reforms in Comparative Economic Systems: Model and Cases. ed., Morris Bornstein, Homewood: Irwin.

Campbell, T.S., and Kracaw. 1993. Financial Institutions and Capital Markets. New York: Harper Collins.

Center, Budget and Policy Priorities. (2017). Policy Basics: public housing. https://www.cbpp.org/research/policy-basics-public-housing

Collingsworth, J. B. 1976. English Housing Trends. London: Allen \& Unwin.

Djermakoyo, IS.1979. The Search for New Economic Order. London: Islamic Council of Europe.

Erikson, A. B. (1985). Social Justice and Public Policy.UK: Wheat Sheaf Books.

https://www.worldcat.org/title/national-dwelling-and-housing-survey.

https://www.bbc.com/news/business-38067626.

Esping Anderson. 1992. The Three Worlds of Welfare Capitalism. Cambridge: Polity Press.

Gilbert, Neil. 2002. Transformation of the Welfare State: The Silent Surrender of Public Responsibility. Oxford: Oxford University Press.

Greenbaum and Thokar. 1990. Contemporary Financial Intermediation. New York: Dryden Press Hayek, Friedrich. 1978. A New Studies in Philosophy, Politics, Economics and the History of Ideas. Chicago: University of Chicago Press.

Ibrahim Warde. 2006. Islamic Finance in the Global Economy. Edinburg: Edinburg University Press. Imran, Umer Chhapra1, Afzal Ahmed,, Raja Rehan, and Farasat Hussain. July 2018. “Consumer's Preference and Awareness: Comparative Analysis between Conventional and Islamic Ijarah Auto Financing in Pakistan". Al-Iqtishad: Jurnal Ilmu Ekonomi Syariah .Journal of Islamic Economics. Volume 10 (2), July 2018. P-ISSN: 2087-135X; E-ISSN: 2407-8654 Page 389 - 402.

Irene Dingeldey and Heinz Rothgang, eds. 2009. Governance of Welfare State Reform. UK: Edward Elger Publishing.

Islamic Banking Bulletin. September 2018. State Bank of Pakistan. @ http://www.sbp.org.pk/ibd/bulletin/2018/Sep.pdf. Accessed on 11-09-19)

Jeffery, R., Frieden. 2006. Global Capitalism: Its Fall and Rise in the Twentieth Century. New York: 
W.W. Norton \& Co.,

Jensen, M. C. 1992. Studies in Theory of Capital Markets.New York: Praeger.

John Commons. 1967. Institutional Economics: Its Place in Political Economy.Madison: University of Wisconsin Press.

Kidwell, D.S., Peterson, R. L. and Blackwell. 1995. Financial Institutions, Market and Money. New York: Dryden Press.

Local Authority Building Control Survey. UK. 2018. https://www.labcwarranty.co.uk/.

Micael Harrington. 1976. The Twilight of Capitalism.New York: Simon \& Schuster.

Mohd, Razali Agus. 2002. The Role of the State and Market in the Housing Sector. Journal of the Housing and the Built Environment. Vol. 17, No. 1.pp.49-67.@www.jstore.org/stable/41107203.

National Model. Economic Development and Cultural Change, Vol. 32, No. 4. 749-766. @ www.jstor.org/stable/1153664

Nicholas Bullock. 2008. 20, 000 Dwellings a Month for Forty Years: France 's Industrialized Housing in the 1950s. The Construction History Society, Vol. 23, pp.59-76. ww.jstore.org/stable/41613928.

Nousheen, Abbas Naqvi and Anila Perveen. 2014. Analysis of Growth of Ijara Investment in Pakistan:A case study on Meezan Bank. KASBIT Business Journal (KBJ), Vol. 7, No.2, 21-34, December 2014. https://kasbit.edu.pk/KBJVol7-2/Chap21-34.pdf). Last accessed on 12-09-19.

Pakistan, Economic Survey. 2017-18. Islamabad: Ministry of Finance. @ http://www.finance.gov.pk/survey/chapters_18/overview.

Pakistan, Bureau of Statistics Report. 2018. https://www.ceicdata.com/en/indicator/pakistan.

Population and Housing Census. 2017; Census 1998 and 2018.

Paul Samuelson. 1965. Economics: An Introductory Analysis, 4th ed. New York: McGraw-Hill, 1965.

Philippe, Annez, and William Wheaten C. July 1984. Economic Development and Housing Sector.

Razi, Naseem. (2016). Transformation of Islamic Economics into a Global Economics: An Analysis in the light of Capitalist and Socialist Systems of Economics. International Journal of Sciences: Basic and Applied Research (IJSBAR), Vol. 30, No 3. 265-282, ISSN 2307-

4531.(http://gssrr.org/index.php?journal=JournalOfBasicAndApplied)

Razi, Naseem. (December 2014). Socio-Ethical Dimensions of Islamic Economy and Issue of Modern Interest and RIBA: An Analysis in the Light of the Economy of the Muslim World. Journal of Islamic Banking and Finance.

Razi, Naseem. Family Planning as National Policy in Pakistan: An Analysis from the Perspective of Shari'ah. Pakistan Journal of Islamic Research, Vol 12, No. 3.21-42. www.bzu.edu.pk.

https://tradingeconomics.com/pakistan/gdp-growth-annual.

Razi, Naseem. Dec. 2014. Islamic Banking System and Mode of Leasing: A Comparative Analysis in the Light of Maqasid al-Shari'ah. Cultural and Religious Studies, Vol. 2, No.6, pp. 349-359.

10.17265/2328-2177/2014.06.005. UK: David Publishing Co.

Robert A. Haugen. 1997. Modern Investment Theory.UK: Prentice-Hall International.

Rodney Wilson. 1997. Economics, Ethics and Religion. London: Macmillan Press Ltd.

Rosser and Rosser.1996. Comparative Economics in a Transforming World Economy. USA: McGraw Hill Inc.,

Severyn T. Bruyn. 1991. A Future for the Market Economy: The Social Market.Stanford: Stanford University Press.

State Bank of Pakistan Report. ( 2010). THE PAKISTAN INFRASTRUCTURE REPORT. Pakistan:

Karachi. http://www.sbp.org.pk/departments/ihfd/InfrastructureTaskForceReport.pdf.

http//devpakistan.com/2017-18.

State Bank of Pakistan. 2019. Policy for Promotion of Low-Cost Housing Finance 2019-2021.

Islamabad: Infrastructure Housing \& SME Finance Department.@

file://C:/Users/care/Desktop/Book\%20on\%20Islamic\%20Finance/Policy-Promotion-Low-CostHousing-Finance.pdf 
Suranyi-Unger. 1980. The Economic Philosophy of the Twentieth Century. Northern Illinois: University Press.

Tatiana, Nenova. (2010). Expanding Housing Finance to the Underserved in South Asia: Market Review and Forward Agenda, India: New Delhi.@ (https://slideplayer.com/slide/734376/).

Towner, R.H. 1977. Religion and the Rise of Capitalism. Hammond's worth.

Todaro, Michael P. 2000. Economic Development. 7th Ed. Longman, Inc.

United Nations Development Report. (2018). www.undp.org.

United Nations Database on Household Size and Composition. (2017).

http://shrinkthatfootprint.com/how-big-is-a-house\#bazcbrUoUABpOVsF.99.

United Nations Development Program. (2018). Human Development Report Pakistan. Islamabad: 4th Floor, Serena Business Complex, Khayaban-e-Suharwardy, Sector G5 -1, 2.

US Census Bureau, Current Population Survey. March 2018. Annual Social and Economic, https://www.census.gov/data/tables/time-series/demo/families/households.htm.

Vinay D. Lall. 1987. Budget and Housing Sector. Economic and Political Weekly, Vol. 22, No. 15. pp.671-675. @www.jstor.org/stable/4376906.

World Bank Group. (November 2018). Pakistan Economic Development Update. Making Growth Matter. At http://www.wbg.org./pk

Yadav, B. S.2009. Virendra Sing and Nandini Sharma. 2008. Economic Reforms and Poverty Alleviation, New Delhi. 